\title{
On Value Premium, Part II: The Explanations
}

\author{
Chi F. Ling ${ }^{1}$, Simon G. M. Koo ${ }^{2}$ \\ ${ }^{1}$ Department of Industrial Engineering and Operations Research, Columbia University, New York, USA \\ ${ }^{2}$ Department of Mathematics and Computer Science, University of San Diego, San Diego, USA \\ Email: c12981@columbia.edu,koo@sandiego.edu
}

Received August 28, 2011; revised October 19, 2011; accepted October 28, 2011

\begin{abstract}
Much academic work has been done to prove that value premium exists. The center of debate however, lies on the reason for its existence. This paper will be a survey on different explanations to the existence of value premium which includes risk premium for value stocks, judgmental bias and agency costs, data mining, survivorship bias and company size's premium. Among all, judgmental bias and agency costs comes out to be the one suffered from least counter-arguments.
\end{abstract}

Keywords: Value Investing; Value Premium; Arbitrage; Value Stocks; Glamour Stocks

\section{Introduction}

While the academic community generally agrees that value investing creates better returns than growth investing, much less consensus exists on the underlying reasons.

This paper will be a survey on different explanations to the value premium. Among all explanations provided, investors' judgmental bias and agency costs seems to be the most plausible explanation.

\section{Explanations for the Value Premium}

\subsection{Risk}

Fama and French [1] argued that value stocks have higher returns because they are riskier. With the use of the Merton's multifactor asset-pricing model [2], [1] were able to link the higher returns of value stocks to higher exposure to financial distress.

However, Lakonishok, Shleifer and Vishny [3] argued against the "metaphysical" approach to risk. In Table 1, they first sorted the stocks into three portfolios according to their cash-to-price ratio (C/P). For example, portfolios labeled " 1 " in row $\mathrm{C} / \mathrm{P}$ have the lowest $\mathrm{C} / \mathrm{P}$, indicating a glamour portfolio, while those labeled " 3 " are value portfolios. Stocks in each portfolio are then further split into three sub-portfolios, according to their sales growth (GS). Here, "3" indicates the highest past sales growth, a glamour stock. $\mathrm{C} / \mathrm{P}=1$ and $\mathrm{GS}=3$ therefore indicate "very glamour" stocks. Value portfolios were, in earlier part of the paper, proved to generate superior return than glamour portfolio (The superior return is often called the value premium. One can refer to [4] for the proof of its existence). The point here is to examine the risk between value and glamour portfolio. One can notice that traditional risk measures such as beta and standard deviation were not notably different across the glamour and value portfolios. However, Lakonishok, Shleifer and Vishny [3] conceded that beta and volatility may not capture all of the relevant risks. Thus, they examined the risk with different approach. By comparing the performance of growth stocks and value stocks in different economic condition, they examined the downside risk of the value strategy which could be one of the factor of value premium not explained by beta and volatility. In Table 2, Panel 1, they then calculated the average monthly return of each

Table 1. Excerpt from lakonishok, shleifer, and vishny (1994)—-traditional risk measures for portfolios.

\begin{tabular}{|c|c|c|c|c|c|c|c|c|c|c|}
\hline & & & & & & & & & & Equally \\
\hline$C / P$ & 1 & 2 & 3 & 1 & 2 & 3 & 1 & 2 & 3 & Weighted \\
\hline$G S$ & 3 & 3 & 3 & 2 & 2 & 2 & 1 & 1 & 1 & Index \\
\hline$\beta$ & 1.249 & 1.296 & 1.293 & 1.239 & 1.184 & 1.214 & 1.330 & 1.258 & 1.322 & 1.304 \\
\hline Standard deviation & 0.216 & 0.232 & 0.241 & 0.215 & 0.207 & 0.213 & 0.242 & 0.224 & 0.241 & 0.250 \\
\hline
\end{tabular}


Table 2. Excerpt from lakonishok, shleifer, and vishny (1994)—performance of portfolios in best and worst times, $1968-1989$. Panel 1: All months in the sample are divided into 25 worst stock return months based on the equally weighted index $\left(W_{25}\right)$, the remaining 88 negative months other than the 25 worst $\left(N_{88}\right)$, the 122 positive months other than the 25 best $\left(P_{122}\right)$, and the 25 best months $\left(B_{25}\right)$ in the sample. Panel 1A: at the end of each April between 1968 and 1989, 9 groups of stocks are formed as follows. All stocks are independently sorted into 3 groups ((1) bottom 340 percent, (2) middle 40 percent, and (3) top 30 percent) by the ratio of previous year's cash flow to end-of-April market value of equity $(C P)$ and by the preformation 5 -year weighted average rank of sales growth (GS). The 9 portfolios are intersections resulting from these 2 independent classifications. For each portfolio (changing every April), Panel 1A presents its average return over the $W_{25}, N_{88}, P_{122}$, and $B_{25}$ months. Panel 1B: at the end of each April between 1968 and 1989, 10-decile portfolios are formed based on the ratio of end-of-previous-year's book value of equity to end-of-April market value of equity $(B / M)$. For each portfolio (changing every April), Panel 1B presents its average return over the $W_{25}, N_{88}, P_{122}$, and $B_{25}$ months. Panels $2 A$ and $2 B$ have the same structure, but the states are defined in terms of the best and worst quarters for GNP growth. All quarters in the sample are divided into 4 sets: 10 quarters of the lowest real GNP growth during the sample period, 34 next lowest real GNP growth quarters, 34 next worst growth quarters, and 10 highest real GNP growth quarters. In Panel $2 \mathrm{~A}$, the value portfolio contains stocks ranking in the top group on $C / P$ and in the bottom group on GS. The Glamour portfolio contains stocks ranking in the bottom group on $C / P$ and in the top group on GS. In panel $2 \mathrm{~B}$, the Value portfolio contains stocks ranking in the top two deciles on $B / M$. The Glamour portfolio contains stocks ranking in the bottom two deciles on $B / M$. The right-most column contains the $t$-statistic for testing the hypothesis that the difference in returns between the Value and Glamour portfolios is equal to zero.

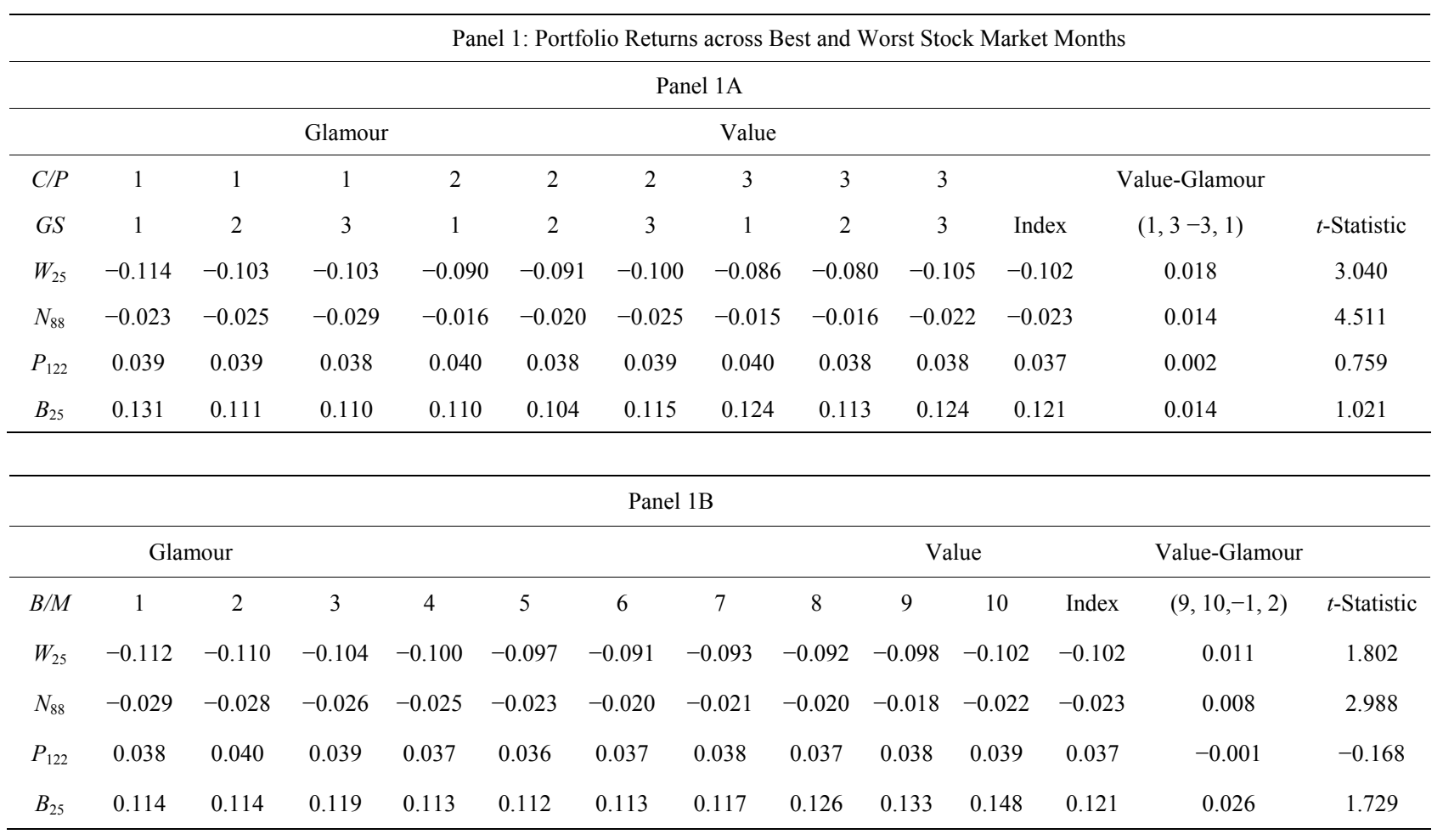

Panel 2: Portfolio Returns across Best and Worst GNP Growth Quarters

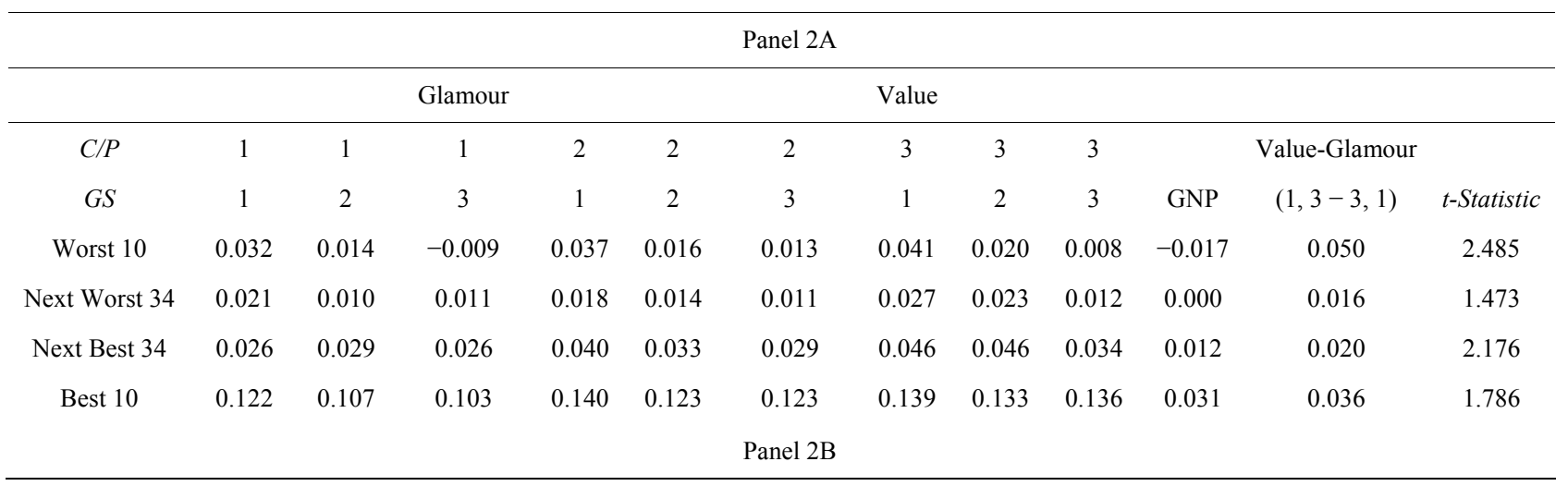


portfolio in four different periods of time. $\mathrm{W}_{25}$ refers to the 25 worst stock return months, $\mathrm{N}_{88}$ the remaining negative months, $\mathrm{B}_{25}$ to the 25 best stock return months, and $\mathrm{P}_{122}$ the 122 positive months other than the 25 best.

They argued that if value stocks are fundamentally riskier, they should underperform relative to the growth stocks during stock market crashes and when the marginal utility of wealth is high. We can see that in the worst 25 months, the value portfolio has a $-8.6 \%$ return, compared to a $-10.3 \%$ return from the glamour portfolio. In the next worst 88 months, the value portfolio has $-1.6 \%$ return, while the glamour portfolio has $-2.9 \%$ return. In the best 25 months, the value portfolio has a return of $12.4 \%$ compared to $11 \%$ for the glamour portfolio. In the next best 122 months, the value portfolio has a return of $4 \%$, compared to $3.8 \%$ for the glamour portfolio. The value portfolio, therefore, has a higher return than the glamour portfolio in every market condition.

This finding supports the idea that value stocks have a lower downside risk than glamour stocks. In Table 2 Panel 2, Lakonishok, Shleifer and Vishny [3] used GNP growth instead of stock return as the indicator of undesirable states. During the worst 10 quarters for GNP growth, value portfolios have a return of $4.1 \%$ compared to $-0.9 \%$ for glamour portfolios. In the next worst 34 quarters, value portfolios generate a $2.7 \%$ return, compared to a $1.1 \%$ return from the glamour portfolios. In the best 10 quarters, the return is $13.9 \%$ vs $10.3 \%$, and in the next best 34 quarters it is $4.6 \%$ compared to $2.6 \%$. Again, value stocks beat glamour stocks each time.

The two findings show that, contrary to the arguments of [1], value stocks actually have less downside risk and suffer less during economic downturns. Further, during states of low distress they perform at least as well as glamour stocks. All in all, the findings don't support the idea that value stocks are fundamentally riskier. However, there are many other proxies for risk, so the risk-based explanation cannot be laid to rest.

\subsection{Judgmental Bias and Agency Costs}

As mentioned in [4], Chan, Karceski, and Lakonishok [5] suggested that investors are prone to judgmental bias (extrapolation bias). In particular, they often extrapolate past performance too far into the future. Table 3 Panel 1 demonstrates this. Here, $\mathrm{AEG}_{(-5,0)}$ represents the average earnings growth of portfolio stocks for five years before they are formed into portfolios. Value stocks tends to have a lower $\mathrm{AEG}_{(-5,0)}$ compared to glamour stock (-27.4\% vs $30.9 \%$ in Panel B), indicating that investors project that glamour stocks' strong past growth will continue. However, as we can see in Panel C, value stocks outperformed glamour stocks in AEG over the five year post-formation period (43.6\% vs 5\%).

The results in Table 3 are echoed by evidence provided by [6]. They argued that if BV/MV is a measure of a company's future growth, then a low BV/MV should indicate high future growth prospects. If this is correct, then a negative correlation should exist between BV/MV and future realized growth.

After comparing BV/MV and subsequent five-yearaverage earnings growth, however, they did not find this to be the case. In fact, the stocks with high earnings growth tended to have a high $\mathrm{BV} / \mathrm{MV}$ at the beginning, while stocks with low BV/MV at the beginning tended to fall short. Nevertheless, the authors found that ex post BV/ MV tracked closely, showing that investors are quick to jump on the bandwagon and chase stocks with high past growth, while punishing stocks with lackluster realized growth.

On the other hand, Chan, Karceski, and Lakonishok [7] also argued that the "agency factor" may play a role in inflating the price of glamour stocks. In order to get commissions, analysts need to convince customers to buy stocks. One way to do this is to show them past data and historical performances. Additionally, Bhushan [8] and Jegadeesh, Kim, Krische and Lee [9] argued that growth stocks tend to come from exciting industries which people prospect a high growth of earnings in the future and are thus easier to tout in analyst reports and media coverage. Thus, in an effort to benefit their careers, many professional money managers will gravitate towards growth-oriented stocks, making glamour stocks over-priced and value stocks under-priced. According to Shleifer and Vishny [10], this mis-pricing pattern can persist over long periods of time.

Nevertheless, La Porta, Lakonishok, Shleifer, and Vishny [11] show that this mispricing gap closes eventually. To make their case, they used evidence taken from periods of earnings announcements for glamour stocks and value stocks, the idea being that earnings announcements contribute strongly to price corrections.

We can see from Table 4 that glamour stocks tend to have a price drop in the first two years after earnings announcements, indicating that investors are disappointed by their subsequent performances. The prices of value stocks, on the other hand, rise after earnings announcements, indicating that investors are surprised by their companies' performances. The difference in the following three years is also statistically significant, showing investors slowly adjusting their expectations. The stock prices are corrected eventually.

We can be fairly certain, therefore, that judgmental bias and agency factors are at least part of the reason of the existence of value premium. Investors and analysts have exaggerated expectations for glamour stocks, and end up disappointed when they fall short. They are overly pessimistic 
Table 3. Excerpt from Lakonishok, Shleifer, and Vishny (1994)-Fundamental variables, past performance, and future performance of glamour and value stocks, 1968-1989. Panel 1: at the end of each April between 1968 and 1989, 10-decile portfolios are formed based on the ratio of end-of-previous-year's book value of equity to end-of-April market value of equity. Numbers are presented for the first (lowest $B / M$ ) and tenth (highest $B / M$ ) deciles. These portfolios are denoted Glamour and Value, respectively. Panel 2: at the end of each April between 1968 and 1989, 9 groups of stocks are formed. The stocks are independently sorted in ascending order into 3 groups ((1) bottom 30 percent, (2) middle 40 percent, (3) top 30 percent) based on $C / P$, the ratio of cash flow to market value of equity, and $G S$, the preformation 5 -year weighted average sales growth rank. Numbers are presented for $\left(C / P_{1}, G S_{3}\right)$, the bottom 30 percent by $C / P$ and the top 30 percent by $G S$, and for $\left(C / P_{3}, G S_{1}\right)$ the top 30 percent by $C / P$ and the bottom 30 percent by $G S$. These portfolios are denoted Glamour and Value, respectively. All numbers in the table are averages over all formation periods. $E / P, C / P, S / P, D / P, B / M$, and $S I Z E$, defined below, use the end-of-April market value of equity and preformation year accounting numbers. $E / P$ is the ratio of earnings to market value of equity. $S / P$ is the ratio of sales to market value of equity. $D / P$ is the ratio of dividends to market value of equity. $B / M$ is the ratio of book value to market value of equity. $S I Z E$ is the total dollar value of equity (in millions). $A E G_{(i, j)}$ is the geometric average growth rate of earnings for the portfolio from year $i$ to year $j . A C G_{(i, j)}$ and $A S G_{(i, j)}$ are defined analogously for cash flow and sales, respectively. $R E T U R N_{(-3,0)}$ is the cumulative stock return on the portfolio over the 3 years prior to formation.

\begin{tabular}{|c|c|c|c|c|}
\hline & \multicolumn{2}{|c|}{ Panel 1} & \multicolumn{2}{|c|}{ Panel 2} \\
\hline & Glamour & Value & Glamour & Value \\
\hline & $B / M_{1}$ & $B / M_{10}$ & $C / P_{1}, G S_{3}$ & $C / P_{3}, G S_{1}$ \\
\hline \multicolumn{5}{|c|}{ Panel A: Fundamental Variables } \\
\hline$E / P$ & 0.029 & 0.004 & 0.054 & 0.114 \\
\hline$C / P$ & 0.059 & 0.172 & 0.080 & 0.279 \\
\hline$S / P$ & 0.993 & 6.849 & 1.115 & 5.279 \\
\hline$D / P$ & 0.012 & 0.032 & 0.014 & 0.039 \\
\hline$B / M$ & 0.225 & 1.998 & 0.385 & 1.414 \\
\hline SIZE & 663 & 120 & 681 & 390 \\
\hline \multicolumn{5}{|c|}{ Panel B: Past Performance — Growth Rates and Past Returns } \\
\hline$A E G_{(-5,0)}$ & 0.309 & -0.274 & 0.142 & 0.082 \\
\hline$A C G_{(-5,0)}$ & 0.217 & -0.013 & 0.210 & 0.078 \\
\hline$A S G_{(-5,0)}$ & 0.091 & 0.030 & 0.112 & 0.013 \\
\hline $\operatorname{RETURN}_{(-5,0)}$ & 1.455 & -0.119 & 1.390 & 0.225 \\
\hline \multicolumn{5}{|c|}{ Panel C: Future Performance } \\
\hline$A E G_{(0,5)}$ & 0.050 & 0.436 & 0.089 & 0.086 \\
\hline$A C G_{(0,5)}$ & 0.127 & 0.070 & 0.112 & 0.052 \\
\hline$A S G_{(0,5)}$ & 0.062 & 0.020 & 0.100 & 0.037 \\
\hline$A E G_{(2,5)}$ & 0.070 & 0.215 & 0.084 & 0.147 \\
\hline$A C G_{(2,5)}$ & 0.086 & 0.111 & 0.095 & 0.088 \\
\hline$A S G_{(2,5)}$ & 0.059 & 0.023 & 0.082 & 0.038 \\
\hline
\end{tabular}

about value stocks, and end up being surprised by their strong performances.

\subsection{Data-Mining}

Lo and MacKinlay [12] argued that the findings of value premium were the result of data-mining; that is, attempting to find a pattern that lacks prediction power. Chan,
Hamao, and Lakonishok [13] addressed this concern by studying the Japanese stock market. The result is shown in Table 5. Sorted by BV/MV (Panel C), the value portfolio (4) has an average monthly return of $2.43 \%$, compared to $1.13 \%$ of the glamour portfolio (1). Sorted by $\mathrm{CF} / \mathrm{P}$ (Panel D), the value portfolio has an average monthly return of $2.22 \%$, whereas the glamour portfolio's is $1.43 \%$. Note that the standard deviation of the 
Table 4. Excerpt from la porta, rafael, josef lakonishok, andrei shleifer, and robert vishny (1997)—annual cumulative earnings announcement returns, 1971-1992. At the end of each June between 1971 and 1992, 10 decile portfolios are formed in ascending order based on the ratio of the book value of equity to market value of equity (BM). The glamour portfolio refers to the decile portfolio containing stocks ranking lowest on BM. The value portfolio refers to the decile portfolio containing stocks ranking highest on BM. The returns presented in the table are averages over all formation periods. Panel A contains (equally-weighted) earnings announcement returns for each portfolio. These are measured quarterly over a 3-day window $(t-1, t+1)$ around The Wall Street Journal publication date and then summed up over the four quarters in each of the first five post-formation years (Q01-Q04, .., Q17-Q20).

\begin{tabular}{ccccccc}
\hline & Glamour & & & Value & Mean Difference & $t$-Stat for Mean \\
\hline BM & 1 & 2 & 9 & 10 & $10-1$ & Difference 10-1 \\
\hline Q01-Q04 & -0.00472 & 0.00772 & 0.03200 & 0.03532 & 0.04004 & 5.65 \\
Q05-Q08 & -0.00428 & 0.00688 & 0.02828 & 0.03012 & 0.03440 & 7.14 \\
Q09-Q12 & 0.00312 & 0.00796 & 0.02492 & 0.03136 & 0.02824 & 5.12 \\
Q13-Q16 & 0.00804 & 0.00812 & 0.02176 & 0.02644 & 0.01840 & 3.67 \\
Q17-Q20 & 0.00424 & 0.01024 & 0.01368 & 0.02432 & 0.02008 & 4.49 \\
\hline
\end{tabular}

value and growth portfolios is very close in both cases, indicating that the value portfolio does not have a higher total risk. This result was similar to [11] which was for the US market. Therefore, given that the same method has led to similar findings in two totally different markets, it is reasonable to conclude that data mining is not driving the results.

Fama and French [1] further supported the existence of the value premium, by testing a board sample of countries. Sorting by BV/MV, E/P, CF/P and dividends to price $(\mathrm{D} / \mathrm{P})$, the value portfolios they used consistently generated superior returns to the glamour portfolios in almost every country. The results are shown in Table 6. Notice that, in general, the standard deviation and return volatilities of the value portfolios are not notably different than the volatilities of the glamour portfolios. Additionally, Davis [14] found value premiums in his study, which used US firms from 1931 to 1960. Capaul, Rowley, and Sharpe [15] found similar results in their studies, which included France, Germany, Switzerland, the United Kingdom, the United States and Japan.

Lakonishok, Shleifer, and Vishny [3] also argued that the value premium reflects an important financial phenomenon rather than a sampling error. They said evidence suggests a systematic pattern of expectation errors on the part of investors, who have been excessively focused on past growth, despite the mean-reverting tendencies of future growth rates. This argument was supported by [16], which showed the existence of a similar pattern of expectation errors. La Porta [16] also demonstrated that growth expectations are less accurate when measured by five-year earnings growth forecasts, rather than by financial ratios such as $\mathrm{E} / \mathrm{P}$ or $\mathrm{C} / \mathrm{P}$.
The evidence supports the view that the cross-sectional differences in returns reflect an economic phenomenon, rather than a statistical fluke.

\subsection{Survivorship Bias}

Banz and Breen [17] and Kothari, Shanken, and Sloan [18] suggests that "survivorship bias" may contribute to value premium. Authors sometimes exclude bankrupted companies in their year-to-year calculations and, as a result, fail to take into account the risk of financial distress in value stocks. Lakonishok, Shleifer, and Vishny [3] addressed this concern by changing the sample selection methodology. First, they required five years of past data to classify firms before measuring their returns, and dismissed the data when survivorship bias was found. Also, they only reported results for the largest $50 \%$ of the firms on the NYSE and AMEX, which have less serious selection bias, according to [16]. That the value premium persists under this methodology provides support that survivorship bias is not the main factor for the value premium. However, the argument of survivorship bias still cannot be laid to rest.

\subsection{Company's Size}

According to Banz [19], a small firm's stock will always have a premium compared to that of a big firm, and this may explained why the value premiums exists. However, Lakonishok, Shleifer, and Vishny [3] and numerous other studies addressed this concern by using size-adjusted returns in their value portfolios. The resulting spread indicates that the value premium cannot be explained by a company's size. 
Table 5. Excerpt from Chan, Hamao, and Lakonishok (1991)—Summary statistics for portfolios sorted by fundamental variables (Japanese Stock Market), 1971-1988. Average monthly returns (standard deviations in parentheses), earnings to price (E/P) ratios, size (millions of yen), book to market $(\mathrm{B} / \mathrm{M})$ ratios, and cash flow to price $(\mathrm{C} / \mathrm{P})$ ratios, for portfolios sorted each June by the four fundamental variables over the period 1971-1988 for both first and second section stocks. Also reported is the estimated beta coefficient from an ordinary least squares regression of portfolio returns on an equally weighted market portfolio of all first and second section stocks. $N$ denotes the average number of securities in each portfolio.

\begin{tabular}{|c|c|c|c|c|c|}
\hline \multicolumn{6}{|c|}{ Panel A: Sorted by Earnings to Price Ratio } \\
\hline & $\leq 0$ & (low) & 2 & 3 & 4(high) \\
\hline \multirow[t]{2}{*}{ Return } & 0.0277 & 0.0154 & 0.0174 & 0.0176 & 0.0194 \\
\hline & $(0.0665)$ & $(0.0427)$ & $(0.0413)$ & $(0.0413)$ & $(0.0425)$ \\
\hline $\mathrm{E} / \mathrm{P}$ & -0.2461 & 0.0214 & 0.0376 & 0.0530 & 0.0955 \\
\hline Size & 27668.5 & 84470.4 & 107703.0 & 86685.0 & 64496.4 \\
\hline $\mathrm{B} / \mathrm{M}$ & 0.2032 & 0.4124 & 0.4665 & 0.5463 & 0.6341 \\
\hline $\mathrm{C} / \mathrm{P}$ & -0.1145 & 0.0938 & 0.1062 & 0.1199 & 0.1799 \\
\hline Beta & 1.1905 & 0.9678 & 0.9529 & 0.9389 & 0.9423 \\
\hline \multirow[t]{3}{*}{$N$} & 105.2 & 275.1 & 279.4 & 279 & 276.2 \\
\hline & & \multicolumn{4}{|c|}{ Panel B: Sorted by Size } \\
\hline & & 1(low) & 2 & 3 & 4(high) \\
\hline \multirow[t]{2}{*}{ Return } & & 0.0244 & 0.0189 & 0.0161 & 0.0147 \\
\hline & & $(0.0542)$ & $(0.0457)$ & $(0.0421)$ & $(0.0408)$ \\
\hline $\mathrm{E} / \mathrm{P}$ & & -0.0083 & 0.0305 & 0.0361 & 0.0402 \\
\hline Size & & 4587.8 & 13699.0 & $36,831.4$ & 262112.0 \\
\hline $\mathrm{B} / \mathrm{M}$ & & 0.5013 & 0.5086 & 0.4870 & 0.4518 \\
\hline $\mathrm{C} / \mathrm{P}$ & & 0.0977 & 0.1080 & 0.0997 & 0.1076 \\
\hline Beta & & 1.0967 & 1.0297 & 0.9638 & 0.8146 \\
\hline \multirow[t]{3}{*}{$N$} & & 308.3 & 310.8 & 312.2 & 315.0 \\
\hline & & anel C: Sort & Market Rat & & \\
\hline & $\leq 0$ & (low) & 2 & 3 & 4(high) \\
\hline \multirow[t]{2}{*}{ Return } & 0.0255 & 0.0133 & 0.0166 & 0.0194 & 0.0243 \\
\hline & $(0.0887)$ & $(0.0431)$ & $(0.0426)$ & $(0.0427)$ & $(0.0464)$ \\
\hline $\mathrm{E} / \mathrm{P}$ & -0.5151 & 0.0211 & 0.0370 & 0.0404 & 0.0441 \\
\hline Size & 10912.5 & 126548.0 & 79794.5 & 65921.5 & 49642.1 \\
\hline $\mathrm{B} / \mathrm{M}$ & -1.0706 & 0.2659 & 0.4292 & 0.5612 & 0.8031 \\
\hline $\mathrm{C} / \mathrm{P}$ & -0.3439 & 0.0746 & 0.1035 & 0.1240 & 0.1486 \\
\hline Beta & 1.1322 & 0.9399 & 0.9822 & 0.9812 & 0.9840 \\
\hline \multirow[t]{3}{*}{$N$} & 16.3 & 305.6 & 307.1 & 307.0 & 306.9 \\
\hline & & anel D: Sor & & & \\
\hline & $\leq 0$ & 1 (low) & 2 & 3 & 4(high) \\
\hline \multirow[t]{2}{*}{ Return } & 0.0262 & 0.0143 & 0.0168 & 0.0190 & 0.0222 \\
\hline & $(0.0705)$ & $(0.0412)$ & $(0.0408)$ & $(0.0430)$ & $(0.0464)$ \\
\hline $\mathrm{E} / \mathrm{P}$ & -0.4265 & 0.0246 & 0.0423 & 0.0510 & 0.0684 \\
\hline Size & 17149.6 & 121298.0 & 75508.4 & 62510.9 & 72388.9 \\
\hline $\mathrm{B} / \mathrm{M}$ & -0.0208 & 0.3783 & 0.4920 & 0.5650 & 0.6170 \\
\hline $\mathrm{C} / \mathrm{P}$ & -0.3303 & 0.0523 & 0.0860 & 0.1242 & 0.2340 \\
\hline Beta & 1.1942 & 0.9247 & 0.9313 & 0.9820 & 1.0135 \\
\hline$N$ & 50.1 & 293.5 & 295.8 & 294.4 & 294.0 \\
\hline
\end{tabular}


Table 6. Excerpt from fama and french (1998) — annual dollar returns in excess of US t-bill rate for market, value and growth portfolio, 1975-1995. Value and growth portfolios are formed on book-to-market equity (B/M), earnings/price (E/P), cashflow/price (C/P), and dividend/price (D/P), as described in Table II. We denote value (high) and growth (low) portfolios by a leading $\mathrm{H}$ or $\mathrm{L}$; the difference between them is $\mathrm{H}-\mathrm{L}$. The first row for each country is the average annual return. The second is the standard deviation of the annual returns (in parentheses) or the $t$-statistic testing whether $H-L$ is different from zero [in brackets].

\begin{tabular}{|c|c|c|c|c|c|c|c|c|c|c|c|c|c|}
\hline & Market & $\mathrm{HB} / \mathrm{M}$ & $\mathrm{LB} / \mathrm{M}$ & H-LB/M & $\mathrm{HE} / \mathrm{P}$ & $\mathrm{LE} / \mathrm{P}$ & H-LE/P & $\mathrm{HC} / \mathrm{P}$ & $\mathrm{LC} / \mathrm{P}$ & H-LC/P & $\mathrm{HD} / \mathrm{P}$ & $\mathrm{LD} / \mathrm{P}$ & $\mathrm{H}-\mathrm{LD} / \mathrm{P}$ \\
\hline \multirow{2}{*}{ U.S. } & 9.57 & 14.55 & 7.75 & 6.79 & 14.09 & 7.38 & 6.71 & 13.74 & 7.08 & 6.66 & 11.75 & 8.01 & 3.73 \\
\hline & (14.64) & $(16.92)$ & (15.79) & [2.17] & (18.10) & (15.23) & 2.28 & (16.73) & (15.99) & [2.08] & (13.89) & (17.04) & {$[1.22]$} \\
\hline \multirow{2}{*}{ Japan } & 11.88 & 16.91 & 7.06 & 9.85 & 14.14 & 6.67 & 7.47 & 14.95 & 5.66 & 9.29 & 16.81 & 7.27 & 9.54 \\
\hline & (28.67) & $(27.74)$ & (30.49) & [3.49] & (26.10) & $(27.62)$ & {$[4.00]$} & (31.59) & $(29.22)$ & [3.03] & (35.01) & $(27.51)$ & [2.53] \\
\hline \multirow{2}{*}{ U.K. } & 15.33 & 17.87 & 13.25 & 4.62 & 17.46 & 14.81 & 2.65 & 18.41 & 14.51 & 3.89 & 15.89 & 12.99 & 2.90 \\
\hline & $(28.62)$ & $(30.03)$ & (27.94) & {$[1.08]$} & $(32.32)$ & $(27.00)$ & {$[0.83]$} & (35.11) & $(26.55)$ & {$[0.85]$} & (32.18) & $(26.32)$ & {$[0.72]$} \\
\hline \multirow{2}{*}{ France } & 11.26 & 17.10 & 9.46 & 7.64 & 15.68 & 8.70 & 6.98 & 16.17 & 9.30 & 6.86 & 15.12 & 6.25 & 8.88 \\
\hline & (32.35) & $(36.60)$ & $(30.88)$ & [2.08] & $(37.05)$ & $(32.35)$ & [2.16] & $(36.92)$ & $(31.26)$ & [2.29] & $(30.06)$ & $(33.16)$ & {$[2.48]$} \\
\hline \multirow{2}{*}{ Germany } & 9.88 & 12.77 & 10.01 & 2.75 & 11.13 & 10.58 & 0.55 & 13.28 & 5.14 & 8.13 & 9.99 & 10.42 & -0.43 \\
\hline & (31.36) & (30.35) & $(32.75)$ & {$[0.92]$} & $(24.62)$ & $(34.82)$ & {$[0.14]$} & (29.05) & (26.94) & {$[2.62]$} & $(24.88)$ & $(34.42)$ & {$[-0.10]$} \\
\hline \multirow{2}{*}{ Italy } & 8.11 & 5.45 & 11.44 & -5.99 & 7.62 & 12.99 & -5.37 & 11.05 & 0.37 & 10.69 & 10.07 & 12.68 & -2.61 \\
\hline & $(43.77)$ & $(35.53)$ & $(50.65)$ & {$[-0.91]$} & $(42.36)$ & $(54.68)$ & {$[-0.84]$} & $(43.52)$ & $(38.42)$ & [1.73] & $(38.28)$ & $(56.66)$ & {$[-0.33]$} \\
\hline \multirow{2}{*}{ Netherlands } & 13.30 & 15.77 & 13.47 & 2.30 & 14.37 & 9.26 & 5.11 & 11.66 & 11.84 & 0.19 & 13.47 & 13.05 & 0.41 \\
\hline & (18.81) & (33.07) & (21.01) & {$[0.44]$} & (21.07) & (20.48) & [1.04] & (33.02) & $(23.26)$ & {$[0.03]$} & (21.38) & $(30.81)$ & {$[0.07]$} \\
\hline \multirow{2}{*}{ Belgium } & 12.62 & 14.90 & 10.51 & 4.39 & 15.12 & 12.90 & 2.22 & 16.46 & 12.03 & 4.44 & 15.16 & 12.26 & 2.91 \\
\hline & $(25.88)$ & $(28.62)$ & (27.63) & [1.99] & $(30.47)$ & (27.88) & {$[0.78]$} & (28.84) & $(25.57)$ & {$[1.27]$} & (26.47) & $(29.26)$ & {$[1.29]$} \\
\hline \multirow{2}{*}{ Switzerland } & 11.07 & 13.84 & 10.34 & 3.49 & 12.59 & 11.04 & 1.54 & 12.32 & 9.78 & 2.53 & 12.62 & 10.44 & 2.18 \\
\hline & $(27.21)$ & $(30.00)$ & $(28.57)$ & {$[0.80]$} & (31.44) & $(28.81)$ & {$[0.36]$} & (36.58) & $(27.82)$ & {$[0.41]$} & $(31.00)$ & $(27.83)$ & {$[0.63]$} \\
\hline \multirow{2}{*}{ Sweden } & 12.44 & 20.61 & 12.59 & 8.02 & 20.61 & 12.42 & 8.19 & 17.08 & 12.50 & 4.58 & 16.15 & 11.32 & 4.83 \\
\hline & $(24.91)$ & (38.31) & $(26.26)$ & [1.16] & (42.43) & (24.76) & {$[1.03]$} & $(30.56)$ & (23.58) & {$[0.90]$} & $(29.55)$ & (25.13) & {$[1.05]$} \\
\hline \multirow{2}{*}{ Australia } & 8.92 & 17.62 & 5.30 & 12.32 & 15.64 & 5.97 & 9.67 & 18.32 & 4.03 & 14.29 & 14.62 & 6.83 & 7.79 \\
\hline & $(26.31)$ & (31.03) & $(27.32)$ & [2.41] & (28.19) & (28.89) & {$[1.71]$} & (29.08) & (27.46) & {$[2.85]$} & (28.43) & $(28.57)$ & {$[1.65]$} \\
\hline \multirow{2}{*}{ Hong Kong } & 22.52 & 26.51 & 19.35 & 7.16 & 27.04 & 22.05 & 4.99 & 29.33 & 20.24 & 9.09 & 23.66 & 23.30 & 0.35 \\
\hline & (41.96) & (48.68) & $(40.21)$ & {$[1.35]$} & (44.83) & $(40.81)$ & {$[0.82]$} & (46.24) & (42.72) & [1.37] & (38.76) & (42.05) & {$[0.09]$} \\
\hline \multirow{2}{*}{ Singapore } & 13.31 & 21.63 & 11.96 & 9.67 & 15.21 & 13.12 & 2.09 & 13.42 & 8.03 & 5.39 & 10.64 & 13.10 & -2.46 \\
\hline & $(27.29)$ & (36.89) & $(27.71)$ & {$[2.36]$} & (29.55) & (34.68) & {$[0.65]$} & (26.24) & (28.92) & [1.49] & (22.01) & $(33.93)$ & {$[-0.45]$} \\
\hline
\end{tabular}

\section{Conclusions}

Though evidence for the value premium is solid, much controversy lays on why this premium exists. One argument is that value stocks are fundamentally riskier. This is not convincing, however, since much research indicates that value portfolios generate higher return even when they have same or lower standard deviation, beta and downside risk.
Another argument is that investors' judgmental bias and the career concerns of portfolio managers cause growth stocks to be overpriced and value stocks to be underpriced. Evidence supports this bias, as well as the meanreverting nature of value stocks, and thus this argument is relatively convincing.

A third argument is that the value premium arises from data mining. This argument is weakened, however, by 
Table 7. Explanations for the existence of the value premium.

\begin{tabular}{|c|c|c|}
\hline Argument & Description & Counter-argument \\
\hline Risk & - Value stocks are fundamentally riskier. & $\begin{array}{l}\text { - The beta and standard deviations of value portfo- } \\
\text { lios are on par with those of growth portfolios. } \\
\text { - Value portfolios possess less downside risk. }\end{array}$ \\
\hline $\begin{array}{l}\text { Behavioral Considerations } \\
\text { and Agency Costs }\end{array}$ & $\begin{array}{l}\text { - Investors extrapolate past performance into future } \\
\text { performance, leading to expectation error. } \\
\text { - Portfolio managers recommend growth stocks to their } \\
\text { clients due to the stocks' attractive past record. }\end{array}$ & - None. \\
\hline Data-mining & $\begin{array}{l}\text { - The value premium is a statistical fluke which has no } \\
\text { explanatory power. }\end{array}$ & $\begin{array}{l}\text { - Studies indicate that value investing works in other } \\
\text { countries. } \\
\text { - There is, in fact, a logical basis for this premium. }\end{array}$ \\
\hline Survivorship Bias & $\begin{array}{l}\text { - Researchers fail to take into account the financial } \\
\text { distress risk. }\end{array}$ & $\begin{array}{l}\text { - Lakonishok, Shleifer, and Vishny (1994) mitigated } \\
\text { this bias in their research and still see the premium. }\end{array}$ \\
\hline Company’s Size & $\begin{array}{l}\text { - The sizes of companies may factor into the value pre- } \\
\text { mium. }\end{array}$ & $\begin{array}{l}\text { - Most studies include size-adjusted returns. } \\
\text { - Most studies seperate large-cap and small-cap stocks } \\
\text { before measuring their returns. }\end{array}$ \\
\hline
\end{tabular}

the evidence of value premiums in non-US markets. Others have contended that survivorship bias may be a factor. But Lakonishok, Shleifer, and Vishny [3] mitigated this bias and still got consistent results.

A final argument is that size factors into the value premium. However, much empirical research uses sizeadjusted returns, with some separating the large-cap and small-cap stocks. This ultimately makes the argument unconvincing.

If expectation errors exist, we can expect to see the value premium continue into the future and value investing will remain rewarding (Table 7).

\section{REFERENCES}

[1] E. F. Fama and K. R. French, "Value versus Growth: The International Evidence," Journal of Finance, Vol. 53, No. 6, 1998, pp. 1975-1999. doi:10.1111/0022-1082.00080

[2] R. Merton, "An Intertemporal Capital Asset Pricing Model," Econometrica, Vol. 41, No. 5 1973, pp. 867-888. doi: $10.2307 / 1913811$

[3] L. Josef, A. Shleifer and R. W. Vishny, "Contrarian Investment, Extrapolation, and Risk," Journal of Finance, Vol. 49, No. 5, 1994, pp. 1541-1578. doi:10.2307/2329262

[4] C. F. Ling and G. M. Koo, "On Value Premium, Part I: The Existence," Journal of Mathematical Finance, Vol. 1, No. 3, 2011, pp. 109-119. doi:10.4236/jmf.2011.13014

[5] L. K. C. Chan, N. Jegadeesh and J. Lakonishok, "Evaluating the Performance of Value versus Glamour Stocks: The Impact of Selection Bias," Journal of Financial Economics, Vol. 38, No. 3, 1995, pp. 269-296. doi:10.1016/0304-405X(94)00818-L

[6] L. K. C. Chan, J. Karceski and J. Lakonishok, "The Level and Persistence of Growth Rates," Journal of Finance, Vol. 58, No. 2, 2003, pp. 643-684. doi:10.1111/1540-6261.00540
[7] L. K. C. Chan, J. Karceski and J. Lakonishok, "New Paradigm or Same Old Hype in Equity Investing?" $F i$ nancial Analysts Journal, Vol. 56, No. 4, 2000, pp. 23-36. doi:10.2469/faj.v56.n4.2371

[8] R. Bhushan, "Firm Characteristics and Analyst Following," Journal of Accounting and Economics, Vol. 11, No. 2-3, 1989, pp. 255-274. doi:10.1016/0165-4101(89)90008-6

[9] N. Jegadeesh, J. Kim, S. Krische and C. M. C. Lee, "Analyzing the Analysts: When Do Recommendations Add Value?" Working Paper, University of Illinois at UrbanaChampaign, Urbana, 2002.

[10] A. Shleifer and R. W. Vishny, "The Limits of Arbitrage," Journal of Finance, Vol. 52, No. 1, 1997, pp. 35-55. doi: $10.2307 / 2329555$

[11] R. La Porta, J. Lakonishok, A. Shleifer and R. Vishny, "Good News for Value Stocks: Further Evidence on Market Efficiency," Journal of Finance, Vol. 52, No. 2 1997, pp. 859-874. doi:10.2307/2329502

[12] A. Lo and C. MacKinlay, "Data-Snooping Biases in Tests of Financial Asset Pricing Models," Review of Financial Studies, Vol. 3, No. 3, 1990, pp. 431-467. doi: $10.1093 / \mathrm{rfs} / 3.3 .431$

[13] L. K. C. Chan, Y. Hamao and J. Lakonishok, "Fundamentals of Stock Return in Japan," Journal of Finance, Vol. 46, No. 5, 1991, pp. 1739-1764. doi: $10.2307 / 2328571$

[14] J. Davis, "The Cross-Section of Realized Stock Returns: The Pre-COMPUSTAT Evidence," Journal of Finance, Vol. 49, No. 5, 1994, pp. 1579-1593. doi: $10.2307 / 2329263$

[15] C. Capaul, I. Rowley and W. Sharpe, "International Value and Growth Stock Returns," Financial Analysts Journal, Vol. 49, 1993, pp. 27-36. doi:10.2469/faj.v49.n1.27

[16] R. La Porta, "Expectations and the Cross-Section of Stock Returns," Harvard University, Harvard, 1993. 
[17] R. Banz and W. Breen, "Sample Dependent Results Using Accounting and Market Data: Some Evidence," Journal of Finance, Vol. 41, No. 4, 1986, pp. 779-793. doi: $10.2307 / 2328228$

[18] S. P. Kothari, J. Shanken and R. Sloan, "Another Look at the Cross-section of Expected Stock Returns," University of Rochester, Rochester, 1992.
[19] R. W. Banz, "The Relationship between Return and Market Value of Common Stock," Journal of Financial Economics, Vol. 9, No. 1, 1981, pp. 3-18. doi:10.1016/0304-405X(81)90018-0 